A. P. POLIVYANCHUK, Doctor of Technical Sciences, Prof.

O. M. Beketov National University of Urban Economy in Kharkiv

17, Marshal Bazhanov Street, Kharkiv, 61002, Ukraine

e-mail: apmail@meta.ua

\title{
INVESTIGATION OF THE INFLUENCE OF THE DISPERSE COMPOSITION OF DIESEL PARTICULATE MATTER ON THE EFFICIENCY OF THEIR RATIONING AND NEUTRALIZATION BY SOOT FILTERS
}

Purpose. Increase in the efficiency of control of diesel particulate matter in the study of the operation of diesel particulate filters by taking into account their particulate composition. Methods. Analysis and synthesis of information in the study of the structure and properties of diesel particulate matter, mathematical modeling in assessing the effectiveness of control and neutralization of particles with soot filters, statistical processing of experimental data, a computational experiment in conducting a comprehensive assessment of the efficiency of the diesel particulate filter. Results. The structure, toxicological properties, dispersed composition and quantitative characteristics of diesel particulate matter are analyzed. The principle of the action of the particulate filter is described. The functions of the distribution densities of countable, surface and mass concentrations of solid particles of various fractions: nuclei, accumulation, large particles are considered. A method for the complex evaluation of the efficiency of a diesel particulate filter on the basis of indices of countable, surface and mass concentrations of particles has been developed. A complex analysis of the efficiency of the diesel particulate filter was carried out. Conclusions. The necessity of taking into account the dispersed composition of diesel solid particles in the analysis of their properties, rationing and the evaluation of the efficiency of the diesel particulate filter is substantiated. It was found that with a high efficiency of reducing the total mass of solid particles in the particulate filter $93.8 \%$, the amount, surface area and mass of fine particles with dimensions of 20-40 nm significantly increase - 4.2, 1.9 and 2.55 times, respectively. The increase in the relative fraction of fine particles after passing through the particulate filter is $72 \%$.

Keywords: diesel engine, brake tester, exhaust gases, particulate matter, concentration, mass emission, particulate filter, efficiency

Полив'янчук А. П.

Харківський національний університет міського господарства імені О.М. Бекетова

ДОСЛІДЖЕННЯ ВПЛИВУ ДИСПЕРСНОГО СКЛАДУ ДИЗЕЛЬНИХ ТВЕРДИХ ЧАСТИНОК НА ЕФЕКТИВНІСТЬ ЇХ НОРМУВАННЯ ТА НЕЙТРАЛІЗАЦЇ̈ САЖОВИМИ ФІЛЬТРАМИ

Мета. Підвищення ефективності контролю дизельних твердих частинок при дослідженні роботи сажових фільтрів за рахунок врахування їх дисперсного складу. Методи. Аналіз і синтез інформації, математичне моделювання, статистична обробка даних, розрахунковий експеримент. Результати. Проаналізовано: структуру, дисперсний склад і кількісні характеристики твердих частинок. Розроблено методику комплексної оцінки ефективності роботи сажового фільтру за показниками лічильної, поверхневої та масової концентрації частинок. Проведено комплексний аналіз ефективності роботи сажового фільтру вантажного автомобіля. Висновки. Обгрунтовано необхідність врахування дисперсного складу дизельних твердих частинок при аналізі їх властивостей, нормуванні та оцінюванні ефективності нейтралізації сажовими фільтрами. Встановлено, що при високій ефективності зниження сумарної маси твердих частинок в сажовому фільтрі кількість, площа поверхні і маса дрібнодисперсних частинок з розмірами 20 ... 40 нм суттєво зростають.

Ключові слова: дизельний двигун, гальмівний стенд, вихлопні гази, тверді частинки, концентрація, масовий викид, сажовий фільтр, ефективність

Поливянчук А. П.

Харьковский национальный университет городского хозяйства имени А.Н. Бекетова

ИССЛЕДОВАНИЕ ВЛИЯНИЯ ДИСПЕРСНОГО СОСТАВА ДИЗЕЛЬНЫХ ТВЕРДЫХ ЧАСТИЦ НА ЭФФЕКТИВНОСТЬ ИХ НОРМИРОВАНИЯ И НЕЙТРАЛИЗАЦИИ САЖЕВЫМИ ФИЛЬТРАМИ

Цель. Повышение эффективности контроля дизельных твердых частиц при исследовании работы сажевых фильтров за счет учета их дисперсного состава. Методы. Анализ и синтез информации, математическое моделирование, статистическая обработка данных, расчетный эксперимент. Результаты. Проанализированы: структура, дисперсный состав и количественные характеристики твердых частиц. Разработана методика комплексной оценки эффективности работы сажевого фильтра по показателям счетной, поверхностной и массовой концентраций частиц. Проведен комплексный анализ эффективности работы сажевого фильтра грузового автомобиля. Выводы. Обоснована необходимость учета дисперсно- 
го состава дизельных твердых частиц при анализе их свойств, нормировании и оценке эффективности нейтрализации сажевыми фильтрами. Установлено, что при высокой эффективности снижения суммарной массы твердых частиц в сажевом фильтре количество, площадь поверхности и масса мелкодисперсных частиц с размерами 20...40 нм существенно возрастают.

Ключевые слова: дизельный двигатель, тормозной стенд, выхлопные газы, твердые частицы, концентрация, массовый выброс, сажевый фильтр, эффективность

\section{Introduction}

Diesel particulate filters are the most common means of diesel particulate matter (PM) neutralization - the second largest (after the $N O_{x}$ ) pollutant in the exhaust of a diesel engine [1]. To evaluate the effectiveness of the filter the criterion of the relative decline of the mass concentration - $C_{m}$ (or emission) of PM as a result of the filtering process is traditionally used. This approach to the evaluation of the effectiveness of diesel particulate filters is not perfect because it does not consider changes in the number concentration - $C_{n}$ (the amount of PM per unit volume) and surface - concentration $C_{s}$ (the total area of the surface of PM per unit volume) of PM. At the same time the value of $C_{n}$ and $C_{s}$ are important toxicological indicators of the extent of the negative impact of diesel particles on the human health and the environment.

A number of of experimental researches [2-7] show diesel particulate filters with high efficiency, determined by the criterion $C_{m}$, miss a significant amount of fine particles, including the most dangerous - nanoparticles (diameter less than $50 \mathrm{~nm}[8,9]$ ) with a high penetration ability to the human respiratory system. The article offers a comprehensive approach to the evaluation of the effectiveness of particulate filters using 3 criteria - values $C_{m}, C_{n}$ and $C_{s}$.

\section{Methods of research}

The aim of this study is to provide a comprehensive evaluation of the efficiency of diesel particulate filters in terms of counting, surface and mass concentrations of PM in accordance with their disperse composition. To achieve this goal the following tasks are performed:

1) the study of the structure and toxicological properties of the diesel particle;

2) analysis of the experimental data on the number, surface area and mass of diesel particulate of various sizes;

3) development of a method of complex estimation of efficiency of the diesel particulate filter; 4) study of the efficiency of the filter using the developed technique.

The structure and toxicological characteristics of the diesel particles.

PM is multicomponent formation composed of the following elements: diesel soot (product of fuel pyrolysis), soluble organic fraction - SOF (fuel and oil hydrocarbons - not burned, condensed and adsorbed on the soot particles surface), sulfates (salts of sulfuric acid) and other inclusions (depreciation products, ash from additives, etc.). The relative proportion of these elements in the PM de- pends on the mode of diesel and vary in wide ranges [10] (Fig. 1).

Negative impact of PM on the environment and humans is caused in three directions:

- particles when inhaled irritate respiratory tract and in case of a chronic exposure cause pulmonary diseases; PM generally have dimensions of $0.1 \ldots 0.54 \mathrm{~mm}$ in diameter and can reach the alveoli of the lungs or can be delayed in the nasal sinuses, trachea or bronchi;

- particles can carry carcinogenic substances that are adsorbed on their surface $(1 \mathrm{~g}$ of carbon (soot) has a surface area of about 75 $\mathrm{m}^{2}$ );

- the presence of suspended particles in the air impairs visibility on roads (automobile exhaust become visible when the concentrations of particles in exhaust gas are $130 \mathrm{mg} / \mathrm{m}^{3}$ and more); particle size of 0.15 microns may be suspended in the air for about 8 days.

In the 90 s of the twentieth century extensive research conducted on toxicology of diesel EG in general and toxicology of diesel particles in particular. World Health Organization (WHO), the International Agency for Re- 


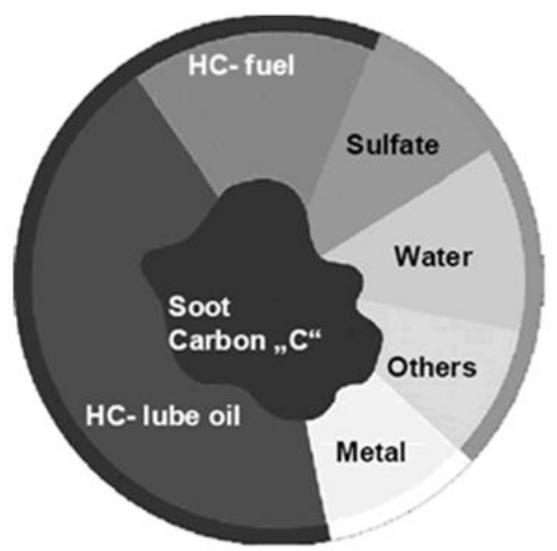

Carbon (soot)

$75 \%(33 \ldots 90 \%)$

Hydrocarbons (SOF) $19 \%$ (7 ... 49\%)

Metals

$2 \%(1 \ldots 5 \%)$

Sulphates, nitrates

$1 \%(1 \ldots 4 \%)$

Water, etc.

$3 \%(1 \ldots 10 \%)$

Fig. 1 - The components included in the PM, and their relative share

search on Cancer (IARC) [11], USA Health Effect Institute (HEI) [12], USA Environmental Protection Agency (EPA) [13, 14] made a conclusion that diesel EG including the PM is the cause of increase of the general morbidity and mortality. Especially dangerous diesel PM are for people working in close proximity to sources of diesel particles emissions, for persons with chronic respiratory diseases, diseases of the cardiovascular system, immune system disorders, for children.

Symptoms of effects caused by shortterm exposure of low levels of diesels EG are determined by medical research of occupational groups that regularly exposed to EG, such as miners, workers of bus depot, shipyards, locomotive depot. The list of emerging deviations include: inflammation of the mucous membranes of the eyes, headache, dizziness, nausea, weakness, tinnitus, oppression of the lung activity, coughing, shortness of breath, etc. After leaving the area of diesel facility operation these symptoms mostly disappear quickly without any significant deviations.

PM and their extracts are found to be mutagenic for bacteria and cell cultures, such as human lymphocytes, reproductive cells [1215]. Currently carcinogenic activity of PM becomes more evident. Diesel particles are classified by the International Agency for Cancer Research (IARC) to group of (probably) carcinogenic to humans [16] and the US Environmental Protection Agency determined as substances that may be carcinogenic with high probability [11]. As the result in more than 30 research papers carried out by the USA Health Effect Institute in different regions for different professional groups, smokers and nonsmokers, it was established that long-time professional impact of diesel EG on human leads to $40 \%$ increase of the relative risk of lung cancer [17]. Largely, due to particles diesel EG have such characteristics. It is associated with the PM properties, particularly their high dispersion and chemical composition.

Comparison of particles sedimentation in different parts of the respiratory system with dispersed composition of diesel aerosol proves that PM is potentially dangerous pollutant of lungs because of their small size. Moreover, the health risk of particles with a diameter 0,1 ... $1 \mathrm{~mm}$, the mass concentration up to $80 \%$, and the rate of sedimentation in the lungs $40 \%$, are on a par with the particles with a diameter less than 0.1 microns, whose number concentration can reach several tens of millions of units per $1 \mathrm{~m}^{3}$ with a coefficient of sedimentation in the lungs $70 \%$.

In general, in lungs of adult while breathing at rest from 12 to $20 \%$ by weight of diesel particles contained in inhaled air is deposited. In childhood, the proportion of PM that are deposited in the lungs is higher than in adults, and the peak of this relationship is at age of five. [18]. Thus, we can assume that children are the second group of risk after people working in the immediate proximity of PM emission sources.

\section{late filter.}

Action principle of the diesel particu-

Diesel particulate filtering was first considered in the 1970s due to concerns regarding the impacts of inhaled particulates. Particulate filters have been in use on non-road machines since 1980, and in automobiles since 1985. Historically medium and heavy duty diesel engine emissions were not regulated until 1987 when the first California Heavy Truck rule was 
introduced capping particulate emissions at $0.60 \mathrm{~g} / \mathrm{BHP}$ Hour. Since then, progressively tighter standards have been introduced for light- and heavy-duty roadgoing dieselpowered vehicles and for off-road diesel engines. Similar regulations have also been adopted by the European Union and some individual European countries, most Asian countries, and the rest of North and South America.

While no jurisdiction has explicitly made filters mandatory, the increasingly stringent emissions regulations that engine manufactures must meet mean that eventually all onroad diesel engines will be fitted with them. In the European Union, filters are expected to be necessary to meet the Euro VI heavy truck engine emissions regulations currently under dis- cussion and planned for the 2012-2013 time frame. In 2000, in anticipation of the future Euro 5 regulations PSA Peugeot Citroën became the first company to make filters standard on passenger cars.

Wall-flow diesel particulate filters usually remove $85 \%$ or more of the soot, and under certain conditions can attain soot removal efficiencies approaching 100\%. Some filters are single-use, intended for disposal and replacement once full of accumulated ash. Others are designed to burn off the accumulated particulate either passively through the use of a catalyst or by active means such as a fuel burner which heats the filter to soot combustion temperatures (Fig. 2).

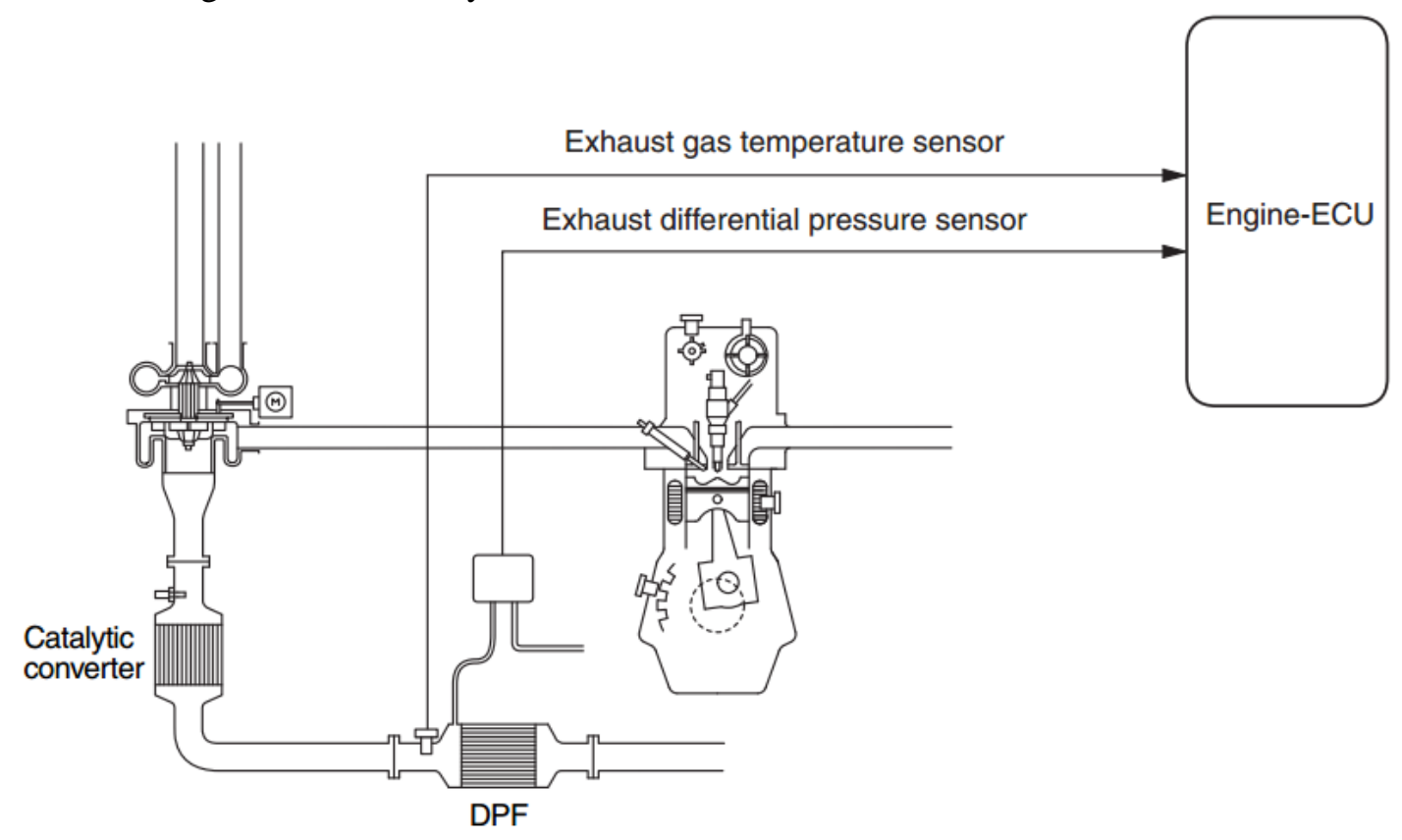

Fig. 2 - The scheme of installation of the diesel particulate filter in the exhaust system of a diesel engine

Diesel engines produce a variety of particles during combustion of the fuel/air mix due to incomplete combustion. The composition of the particles varies widely dependent upon engine type, age, and the emissions specification that the engine was designed to meet. Two-stroke diesel engines produce more particulate per unit of power than do four-stroke diesel engines, as they burn the fuel-air mix less completely.

Diesel particulate matter resulting from the incomplete combustion of diesel fuel produces soot (black carbon) particles. These particles include tiny nanoparticles - smaller than a thousandth of a millimeter (one micron).
Soot and other particles from diesel engines worsen the particulate matter pollution in the air and are harmful to health. New particulate filters can capture from $30 \%$ to greater than $95 \%$ of the harmful soot. With an optimal diesel particulate filter (DPF), soot emissions may be decreased to $0.001 \mathrm{~g} / \mathrm{km}$ or less.

The quality of the fuel also influences the formation of these particles. For example, a high sulfur content diesel produces more particles. Lower sulfur fuel produces fewer particles, and allows use of particulate filters. The injection pressure of diesel also influences the formation of fine particles. 
Filters require more maintenance than catalytic converters. Ash, a byproduct of oil consumption from normal engine operation, builds up in the filter as it cannot be converted into a gas and pass through the walls of the filter. This increases the pressure before the filter. Regular filter maintenance is a necessity.

Experimental data on the $C_{m}, C_{n}$ and $C_{s}$ value.

The results of experimental studies on the particle size influence at the number, sur- face and mass concentration, generalized for different types of diesel engines, are shown in Fig. 3 [19].

When considering the dispersed composition of PM three particle size ranges can be distinguished: fraction of nuclei $-3 \ldots 30 \mathrm{~nm}$; fraction of accumulation $-30 \ldots 500 \mathrm{~nm}$ and the fraction of large particles - diameter greater than $1000 \mathrm{~nm}$ (1 micron). Presented in Fig. 3 diagrams of density distribution functions for

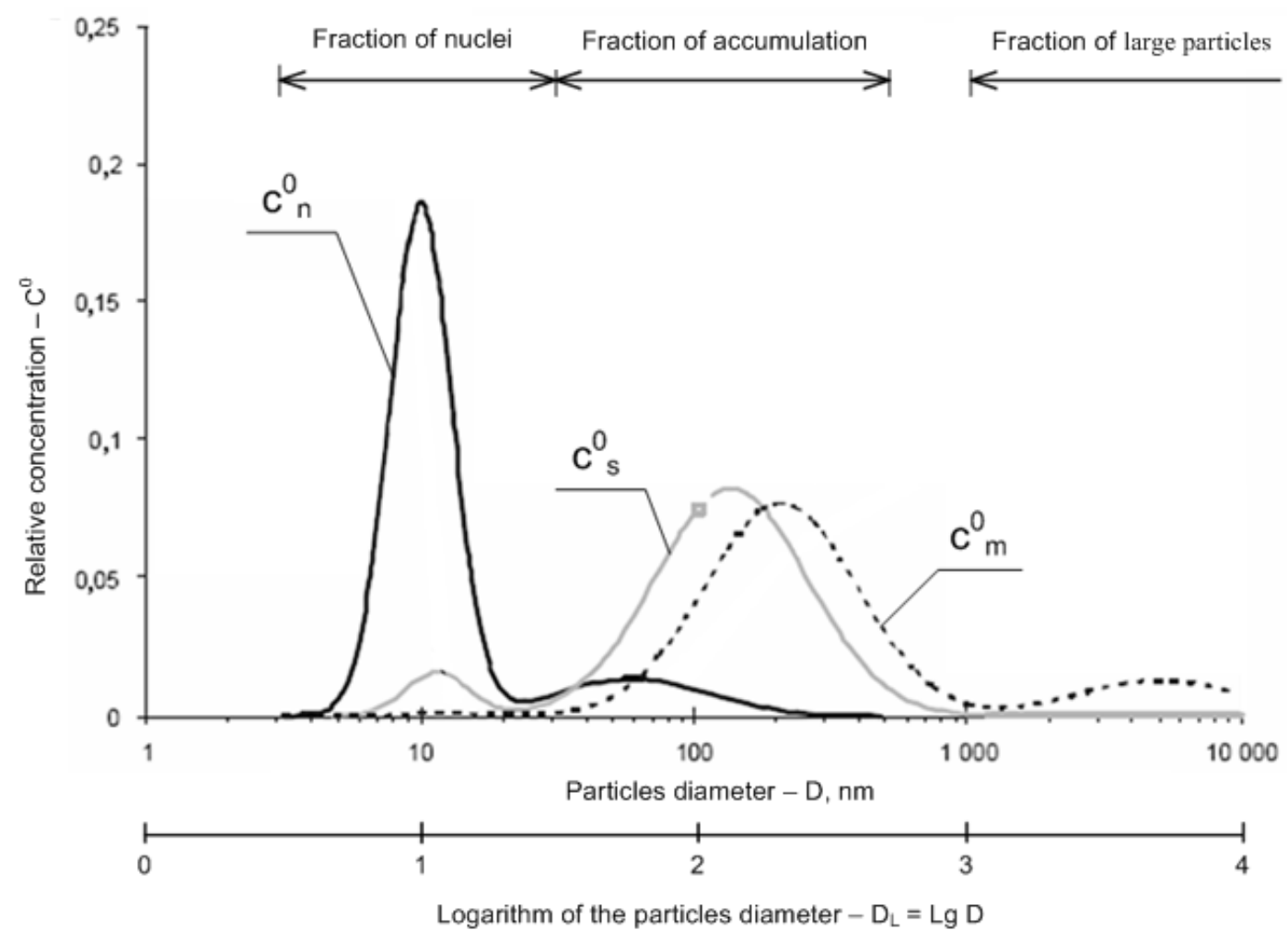

Fig. 3 - The function of the density distribution of the relative number, surface and mass concentrations of PM

the relative number, surface and mass concentrations of PM - $c^{0}{ }_{n}, c^{0}{ }_{s}$ and $c^{0}{ }_{m}$ reflect the following properties of diesel particles:

- a fraction of nuclei constitute the greater number of the PM - $90 \%$ of the total, $20 \%$ of the total surface area and $5 \%$ of the total mass; $80 \%$ of particles and $15 \%$ of the total surface area accounts for a range of $10 \pm 5 \mathrm{~nm}$, wherein curves $c_{n}^{0}$ and $c_{s}^{0}$ have maximum;

- relative proportion of particles of accumulation fractions constitute $20 \%$ of the total, $80 \%$ of the total surface area and $85 \%$ of the total mass; in the fraction the highest number of particles $(12 \%)$ is in the range of 30 $\ldots 100 \mathrm{~nm}$, curves $c^{0}{ }_{s}$ and $c^{0}{ }_{m}$ take the maximum values within the ranges $100 \ldots 200 \mathrm{~nm}$ and $150 \ldots 300 \mathrm{~nm}$ respectively;
- a fraction of large particles is characterized by the lowest values of number $-2 \%$, the total surface area $-1 \%$ and mass $-4 \%$.

The data presented in Fig. 3, in addition to information about values of $c^{0}{ }_{n}, c^{0}{ }_{s}$ and $c^{0}{ }_{m}$ functions reflect their relationship and make it possible to change one function to evaluate changes in the other two. This property was used in developing the methodology presented below.

Methods of integrated assessing of the efficiency of diesel particulate filter

The efficiency of the filter usage is proposed to assess along the 3 indicators of relative decline of number, surface and mass concentrations, defined by the following generalized formula: 


$$
\exists_{y}=\frac{\left(C_{y}\right)_{n / f}-\left(C_{y}\right)_{f}}{\left(C_{y}\right)_{n / f}} \cdot 100 \%,
$$

where: $\ni_{p}$ - the efficiency of the filter as measured by $p$, which is defined as following: number $-n$, surface $-s$ or mass - $m$ of PM; $\left(C_{p}\right)_{n f f}$ and $\left(C_{p}\right)_{f}$ - total relative concentrations of particles within the size range under consideration, both in the absence of diesel particulate filter and while its using. formula:

The values of $C_{p}$ are determined by the

$$
C_{y}=\int_{D_{L}}^{D_{L 2}} c_{y}\left(D_{L}\right) \cdot d D_{L}
$$

where: $D_{L 1}, D_{L 2}$ - initial and final value of the size range (diameters) of PM on a scale of base-10 logarithm; $c_{p}\left(D_{L}\right)$ - the probability density function of indicator $p$.

$c_{p}\left(D_{L}\right)$ function is determined on the basis of generalized distribution functions $c^{0}{ }_{n}, c^{0}{ }_{s}$ and $c_{m}^{0}$, , shown in Fig. 3, as well as the wellknown experimental distribution function of one of the indicators (denoted $\left.p^{*}\right)-c_{p^{*}\left(D_{L}\right) \text { : }}^{r}$

$$
c_{p}\left(D_{L}\right)=K_{,}\left(D_{L}\right) \cdot K_{p}\left(D_{L}\right) \cdot c_{\rho}^{\prime} \cdot\left(D_{L}\right) \text {, }
$$

where: $K_{r}\left(D_{L}\right)$ - correction function of experimental data; $K_{p}\left(D_{L}\right)$ - a function of the transition from indicator $\mathrm{p}$ *to indicator $\mathrm{p}$.

Functions $K_{r}$ и $K_{p}$ is obtained by using the following expressions:

$$
\begin{aligned}
& K_{r}\left(D_{L}\right)=\frac{c_{p^{*}}^{\gamma}\left(D_{L}\right)}{c_{y}^{0}\left(D_{L}\right)} ; \\
& K_{p}\left(D_{L}\right)=\frac{c_{y}^{0}\left(D_{L}\right)}{c_{\gamma^{*}}^{0}\left(D_{L}\right)},
\end{aligned}
$$

where: $c_{p}^{0}\left(D_{L}\right)$ - generalized value of function of the density distribution (probability density function) for the indicator $\mathrm{p} ; c_{p^{*}}^{0}\left(D_{L}\right)$ - generalized value of probability density function for the indicator $\mathrm{p} *$.

For example, if the experimental dependence $c^{r}{ }_{n}\left(D_{L}\right)$ is known, than a density distribution function of mass concentration determined by the expression (3) is as follows:

$$
\begin{aligned}
& c_{m}\left(D_{L}\right)=K_{r}\left(D_{L}\right) \cdot K_{m}\left(D_{L}\right) \cdot c_{n}^{\gamma}\left(D_{L}\right)= \\
& =\frac{c_{n}^{\gamma}\left(D_{L}\right)}{c_{n}^{0}\left(D_{L}\right)} \cdot \frac{c_{m}^{0}\left(D_{L}\right)}{c_{n}^{0}\left(D_{L}\right)} \cdot c_{n}^{r}\left(D_{L}\right)
\end{aligned}
$$

\section{Results and discussion}

Comprehensive evaluation of the freight car diesel particulate filter with known correlation between number concentration and particle size carried out using proposed method [3] (Fig. 4).
Two areas are identified in the researched range of particle sizes - $20 \ldots 600 \mathrm{~nm}$ : $1^{\text {st }}-20 \ldots 40 \mathrm{~nm}$ - an area where the number concentration increased after the filter application, $2^{\text {nd }}--40 \ldots 600 \mathrm{~nm}$ - an area where the number concentration decreased.

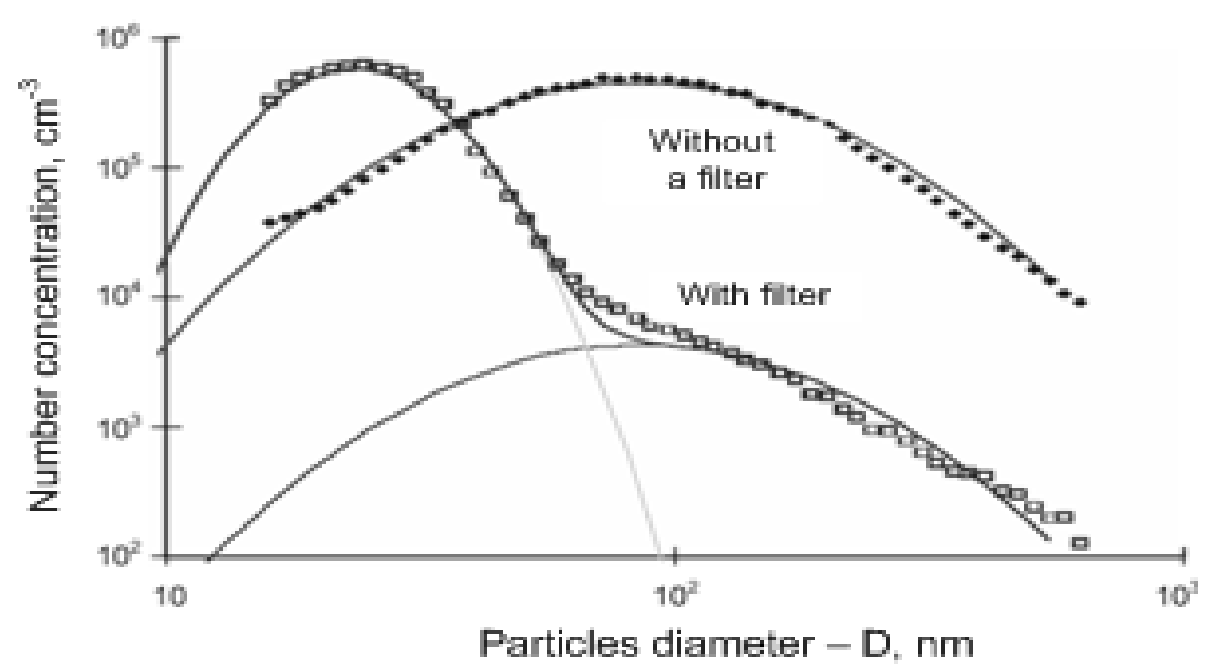

Fig. 4 - The results of experimental research of PM number concentration 
Fig. 5 and 6 present the results of determining the $c_{s}$ and $c_{m}$ functions, obtained using the expression (3), and indicators of the filter

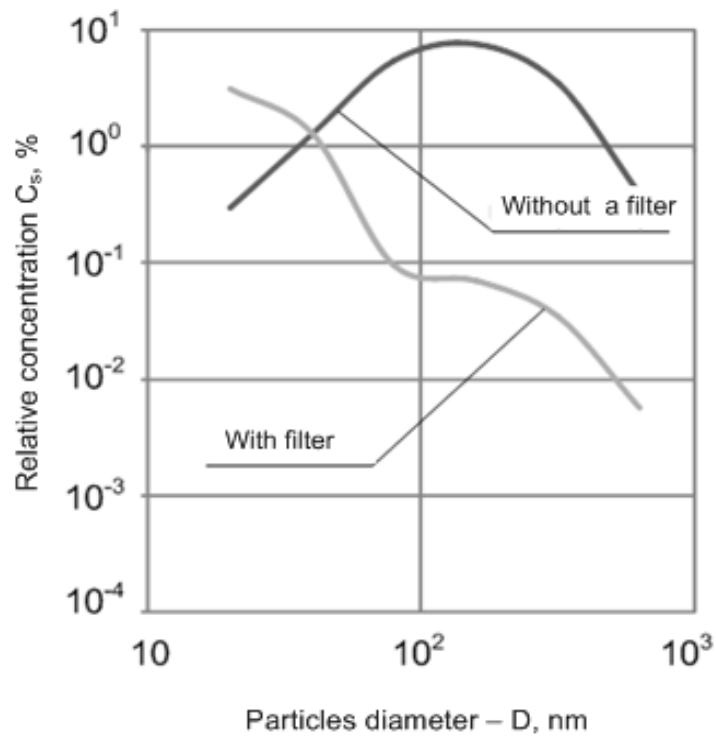

efficiency calculated using the expression (1). Method of trapezoids was used for integrals calculations (2) [20].

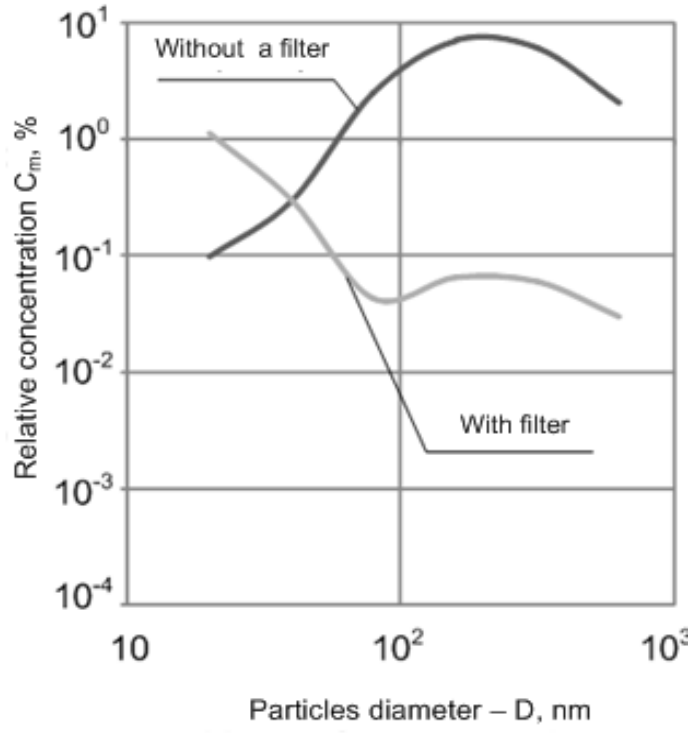

Fig. 5 - The values of the function of the density distribution $c_{s}$ and $c_{m}$ for the studied filter

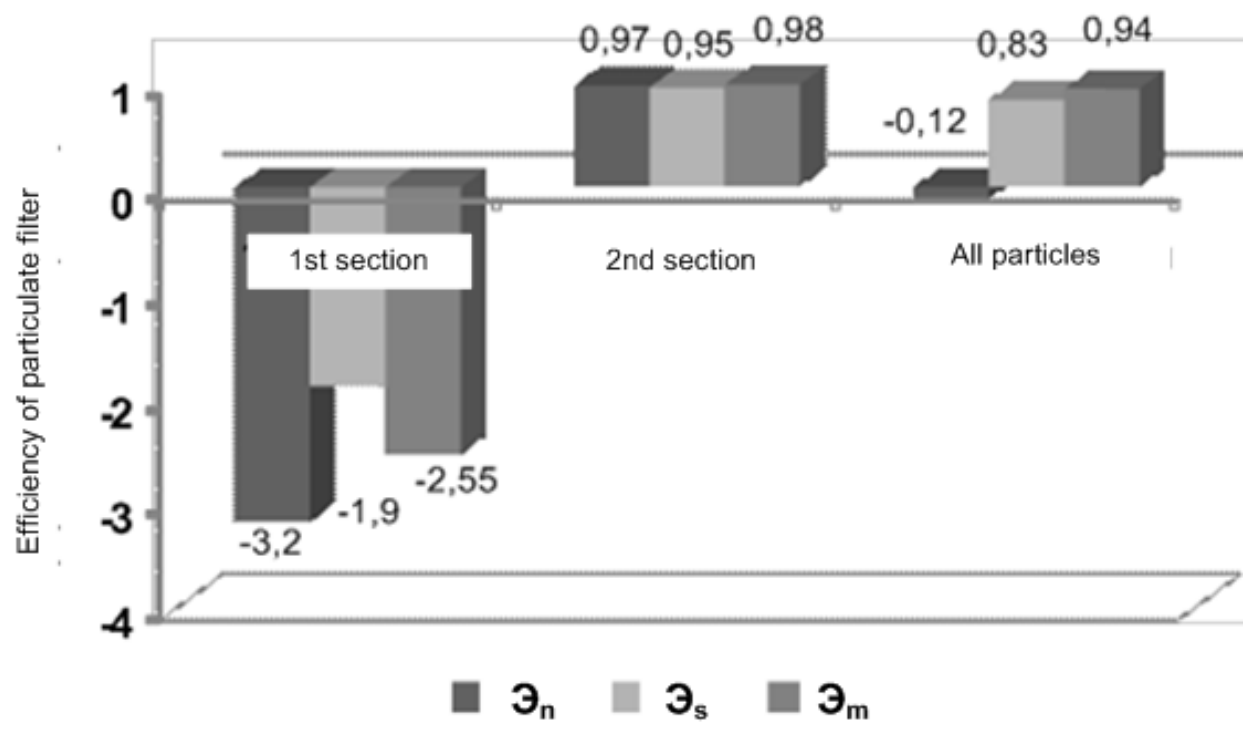

Fig. 6 - Efficiency indicators of studied diesel particulate filter

The research results show:

- The amount of PM: at the $1^{\text {st }}$ section increased 4.2 times, at the $2^{\text {nd }}$ section reduced by 30.5 times, over the whole range increased by $12 \%$;

- the surface area of the particles at the $1^{\text {st }}$ section increases 2.9 times, at the $2^{\text {nd }}$ section reduced by 18.2 times, over the whole range decreased by 5.9 times;

- the mass of PM: at the $1^{\text {st }}$ section - increases 3.55 times, at the $2^{\text {nd }}$ section - reduced by 49.1 times, over the whole range reduced by 16.1 times.

Thus, with a substantial reduction of the total surface and mass of all particles their total number increases through the increase of the number of fine particles measuring $20 \ldots 40 \mathrm{~nm}$. The relative proportion of these particles passing through the filter increases from $26 \%$ to $98 \%$. 


\section{Conclusions}

1. Fractional composition of captured particles is necessary to take into consideration while evaluating the efficiency of the particulate filter.

2. Developed a method of a complex estimation of efficiency of the diesel particulate filter according to three criteria: the counting, the surface and the mass concentration of particulate matter in view of the particulate composition.
3. Comprehensive assessment of the efficiency of the studied filter showed the significant decrease of the mass concentration of the total PM flow - by $93.8 \%$, while there was a significant increase of number -4.2 times, surface area -1.9 times and mass -2.55 times of the fine particles measuring $20 \ldots 40 \mathrm{~nm}$.

1. Поливянчук А., Щепак Е., Титова Е. Исследование степени токсичности вредных веществ, выбросы которых нормируются европейскими экологическими стандартами. Вестник Национального технического университета „ХПИ”. 2007. №2. С. 112-115.

2. Mayer A. Curtailing emissions of diesel engines in tunnel sites . MTZ: Motortech. 2014. №2. 13p.

3. Burtscher H. Literature Study on Tailpipe Particulate Emission Measurement for Diesel Engines . GRPE . Fachhochschule Aargau, University of Applied Science. 2001. 45 p.

4. Dvulit Z., Bojko O. Towards sustainable transport in Ukraine: main obstacles and directions of development. ECONTECHMOD. 2014. Vol. 3, №2. P. 7-14.

5. Batluk V., Romantsov E., Klymets V. The problem of highly effective cleaning of air from dust. ECONTECHMOD. 2013. Vol. 2, №2. P. 17-25.

6. Звонов В., Корнилов Г., Козлов А., Симонова Е. Оценка и контроль выбросов дисперсных частиц с отработавшими газами дизелей. М.: Издательство Прима-Пресс. 2005. 312 с.

7. Polivyanchuk A., Parsadanov I., Holkina E. Creation and experimental studies of the dynamic measuring concentrations of particulates in the exhaust gases of diesel engines. TEKA. Commission of motorization and energetics in agriculture. 2015. Vol. 15, №2. P. 15-24.

8. Kittelson D., Megan A., Watts W. Review of diesel particulate matter sampling methods: Final Report. University of Minnesota, Minneapolis, MN. 1999. 63p.

9. Mundt D.J., Nauss K.H., Gohen A.J., Greenbaum D.S. Diesel emission and lung cancer: epidemiology and quantitative risk assessment: A special report of the Institute Diesel Epidemiology Expert Panel . Health Effect Institute. 2013. 74p.

10. Dawson D.S., Alexeeff G.V., Budroe J.D., Campelman S.V. For the proposed identification of diesel exhaust as toxic air contaminant. Part B: Health risk assessment for diesel exhaust. Office of Environmental Health Hazard Assessment, Air Toxicology and Epidemiology Section. 1998. 442p.

11. Draper W.M., Phillips J.A., Zeller H.W. Impact of barium fuel additive on the mutagenicity and polycyclic aromatic hydrocarbon content of diesel exhaust particulate emissions. SAE Technical Papers. 1988. №881651, $19 \mathrm{p}$.

12. Shore P.R., Tesh J.M., Bootman J.C. Application of short-term bioassays to the assessment of engine exhaust emissions. SAE Technical Papers. 1987. №870627. 16p.

13. Nauss, K. Diesel exhaust: a critical analysis of emission exposure and health effects .Summary of HEI special report. 1997. 6p.

14. Поливянчук А.П., Львов С.А. Определение регрессионных зависимостей для оценки содержания твердых частиц в отработавших газах дизеля. Вісник Східноукраїнського наџіонального університету ім. Даля. 2013. № 17 (206). С. 99-104.

15. Bahadur R. Impact of California's air pollution laws on black carbon and their implications for direct radiative forcing. Atmospheric Environment. 2011. №45. P. 1162-1167.

16. Scoltock J. Diesel Particulate Filter: PSA Peugeot Citroën was the first to bring in particulate filters to help make diesels cleaner. Automotive Engineer. 2014. Vol. 1, №4. Р. 4-7.

17. Поливянчук А.П., Парсаданов И.В., Рыкова И.В. Определение и анализ уровней выбросов твердых частиц с отработавшими газами автомобильного дизеля на установившихся режимах работы. Двигатели внутреннего сгорания. 2009. №1. С. 92-96.

18. Поливянчук А.П. Повышение точности гравиметрического метода измерений удельного выброса твердых частиц с отработавшими газами дизеля. Двигатели внутреннего сгорания. 2010. №2. С. 110-113.

19. Поливянчук А.П. Оценка неопределенности результатов измерений выбросов твердых частиц в ходе экологических испытаний дизелей. Вісник Східноукраӥнського національного університету ім. В. Даля. 2012. №5 (176). С. 121-128.

20 . Стенцель Й. Метрологія та технологічні вимірювання в хімічній промисловості, аналітичні прилади та методи контролю. Луганськ: Видавництво СНУ ім. В. Даля. 2001. 269 с. 


\section{References}

1. Polivyanchuk, A., Shtepak, E., Titova, E. (2007). Issledovanie stepeni toksichnosti vrednyh veshchestv, vybrosy kotoryh normiruyutsya evropejskimi ehkologicheskimi standartami. [Study degree of toxicity of pollutants, emissions are standardized European environmental standards]. Bulletin of the National Technical University "KHPI", 2, 112-115. [in Russian].

2. Mayer, A. (2014). Curtailing emissions of diesel engines in tunnel sites. MTZ: Motortech, 2, 13. [in English].

3. Burtscher, H. (2001). Literature Study on Tailpipe Particulate Emission Measurement for Diesel Engines. GRPE. Fachhochschule Aargau, University of Applied Science, 45. [in English].

4. Dvulit, Z., Bojko, O. (2014). Towards sustainable transport in Ukraine: main obstacles and directions of development. ECONTECHMOD, 3(2), 7-14.

5. Batluk, V., Romantsov, E., Klymets, V. (2013). The problem of highly effective cleaning of air from dust. ECONTECHMOD, 2(2), 17-25. [in English].

6. Zvonov, V., Kornilov, G., Kozlov, A., Simonova, E. (2005). Ocenka i kontrol' vybrosov dispersnyh chastic s otrabotavshimi gazami dizelej. [Assessment and emission control particulate matter from the exhaust gases of diesel engines]. Moscow. Publishing house: «Prima press», 312 [in Russian].

7. Polivyanchuk ,A., Parsadanov, I., Holkina, E. (2015). Creation and experimental studies of the dynamic measuring concentrations of particulates in the exhaust gases of diesel engines. TEKA. Commission of motorization and energetics in agriculture, 15(2), 15-24. [in English].

8. Kittelson, D., Megan, A., Watts, W. (1999). Review of diesel particulate matter sampling methods: Final Report. University of Minnesota, Minneapolis, MN, 63. [in English].

9. Mundt, D.J., Nauss, K.H., Gohen, A.J., Greenbaum, D.S. (2013). Diesel emission and lung cancer: epidemiology and quantitative risk assessment: A special report of the Institute Diesel Epidemiology Expert Panel. Health Effect Institute, 74. [in English].

10. Dawson, D.S., Alexeeff, G.V., Budroe, J.D., Campelman, S.V. (1998). For the proposed identification of diesel exhaust as toxic air contaminant. Part B: Health risk assessment for diesel exhaust. Office of Environmental Health Hazard Assessment, Air Toxicology and Epidemiology Section, 442. [in English].

11. Draper, W.M., Phillips, J.A., Zeller, H.W. (1988). Impact of barium fuel additive on the mutagenicity and polycyclic aromatic hydrocarbon content of diesel exhaust particulate emissions. SAE Technical Papers, 881651, 19. [in English].

12. Shore, P.R., Tesh, J.M., Bootman, J.C. (1987). Application of short-term bioassays to the assessment of engine exhaust emissions. SAE Technical Papers, 870627, 16. [in English].

13. Nauss, K. (1997). Diesel exhaust: a critical analysis of emission exposure and health effects. Summary of HEI special report, 6. [in English].

14. Polivianchuk, A.P., Lvov, S.A. (2013). Opredelenie regressionnyh zavisimostej dlya ocenki soderzhaniya tverdyh chastic $\mathrm{v}$ otrabotavshih gazah dizelya. [Determining the regressional dependence to assess the solids content in exhaust gases of diesel engine]. Visnik of the Volodymyr Dahl East Ukrainian national university, 17 (206), 99-104. [in Russian].

15. Bahadur, R. (2011). Impact of California's air pollution laws on black carbon and their implications for direct radiative forcing. Atmospheric Environment, 45. 1162-1167 [in English].

16. Scoltock, J. (2014). Diesel Particulate Filter: PSA Peugeot Citroën was the first to bring in particulate filters to help make diesels cleaner. Automotive Engineer, 1(4), 4-7. [in English].

17. Polivyanchuk, A. P., Parsadanov, I.V., Rykova, I.V. (2009). Opredelenie i analiz urovnej vybrosov tverdyh chastic s otrabotavshimi gazami avtomobil'nogo dizelya na ustanovivshihsya rezhimah raboty. [Determination and analysis of the levels of emissions of particulates with exhaust gases of automotive diesel engine in steady running]. Internal combustion engines, 1, 92-96. [in Russian].

18. Polivyanchuk, A.P. (2010). Povyshenie tochnosti gravimetricheskogo metoda izmerenij udel'nogo vybrosa tverdyh chastic s otrabotavshimi gazami dizelya. [Improving accuracy of gravimetric measurement method for specific emission of particulate matter with exhaust gases of a diesel engine]. Internal combustion engines, 2 , 110-113. [in Russian].

19. Polivyanchuk, A.P. (2012). Ocenka neopredelennosti rezul'tatov izmerenij vybrosov tverdyh chastic v hode ehkologicheskih ispytanij dizelej [Uncertainty estimate in the results of measurement of particulate emissions during the environmental testing of diesel engines]. Visnik of the Volodymyr Dahl East Ukrainian national university, 5 (176), 121-128. [in Russian].

20 . Stenchel, I. (2001). Metrolohiya ta tekhnolohichni vymiryuvannya v khimichniy promyslovosti, analitychni prylady ta metody kontrolyu [Metrology and measurement technology in the chemical industry, analytical instrumentation and control]. Lugansk: Publishing house Volodymyr Dahl East Ukrainian National University, 269 [in Ukrainian].

Надійшла до редколегії 13.08.2017 